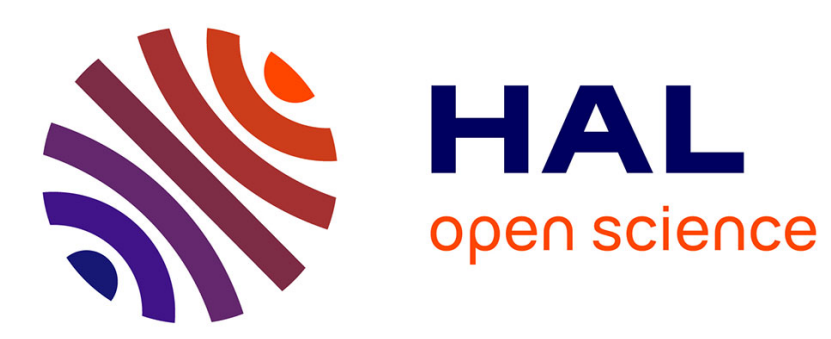

\title{
Box model for radon transfers into the stratosphere
}

\author{
G. Lambert, J.-C. Le Roulley, M. Kritz
}

\section{To cite this version:}

G. Lambert, J.-C. Le Roulley, M. Kritz. Box model for radon transfers into the stratosphere. Tellus B - Chemical and Physical Meteorology, 1990, 42 (1), pp.135 - 141. 10.3402/tellusb.v42i1.15197. hal-03582293

\section{HAL Id: hal-03582293 \\ https://hal.science/hal-03582293}

Submitted on 21 Feb 2022

HAL is a multi-disciplinary open access archive for the deposit and dissemination of scientific research documents, whether they are published or not. The documents may come from teaching and research institutions in France or abroad, or from public or private research centers.
L'archive ouverte pluridisciplinaire $\mathbf{H A L}$, est destinée au dépôt et à la diffusion de documents scientifiques de niveau recherche, publiés ou non, émanant des établissements d'enseignement et de recherche français ou étrangers, des laboratoires publics ou privés. 


\section{Tellus B: Chemical and Physical Meteorology}

\section{Box model for radon transfers into the stratosphere}

\section{G. Lambert, J.-C. Le Roulley \& M. Kritz}

To cite this article: G. Lambert, J.-C. Le Roulley \& M. Kritz (1990) Box model for radon transfers into the stratosphere, Tellus B: Chemical and Physical Meteorology, 42:1, 135-141, DOI: 10.3402/ tellusb.v42i1.15197

To link to this article: https://doi.org/10.3402/tellusb.v42i1.15197

$$
\begin{aligned}
& \text { (c) } 1990 \text { The Author(s). Published by Taylor \& } \\
& \text { Francis. }
\end{aligned}
$$

曲 Published online: 18 Jan 2017.

Submit your article to this journal $־$

Џ Article views: 34

Q View related articles ¿ 


\title{
Box model for radon transfers into the stratosphere
}

\author{
By G. LAMBERT ${ }^{1}$, J.-C. LE ROULLEY ${ }^{1}$ and M. KRITZ ${ }^{2},{ }^{1}$ Centre des Faibles Radioactivités, ${ }^{*}$ \\ Laboratoire Mixte CNRS-CEA, 91198 Gif-sur-Yvette Cedex, France; \\ ${ }^{2}$ Atmospheric Sciences Research Center, State University of New York, Albany, NY 12222, USA
}

(Manuscript received 30 December 1988; in final form 9 June 1989)

\begin{abstract}
There is experimental evidence that the stratospheric reservoir of $\mathrm{Pb}-210$ aerosols is fed from the troposphere by injections into the stratosphere of its mother nuclide Rn-222. In steady state conditions, it is possible to calculate, for the tropospheric air penetrating into the stratosphere, that an $\mathrm{Rn}-222$ concentration of $10 \mathrm{pCi} \mathrm{kg}-1$ is necessary to balance the stratospheric $\mathrm{Pb}-210$ losses. This concentration is not typical of the values usually measured in the upper troposphere. This supports the idea that the troposphere-to-stratosphere transfers are discontinuous and occur following a strong tropospheric upward transport.
\end{abstract}

\section{Introduction}

It is generally admitted that stratospheric ozone strongly depends on a large number of molecules and radicals originating from the Earth's surface. Some of them have a rather long life and are reasonably taken into account by simple $1 \mathrm{D}$ or $2 \mathrm{D}$ models. In contrast, it is much more difficult to parameterize short-lived species (days or weeks) for which the atmospheric distribution is patchy. Moreover in this case, the vertical transfer from the ground level toward the stratosphere becomes a very important parameter.

In the case of water vapour, Brewer (1949) and Newell (1981) pointed out that comparing its stratospheric mixing ratios to the tropopause temperatures distribution introduces a constraint in the troposphere-to-stratosphere exchange processes. The aim of this paper is to determine what constraints are introduced in this problem by the radon-222 measurements. In effect, such an approach is particularly tempting, because radon is a noble gas whose isotope 222 has a wellknown radioactive half-life of 3.8 days and whose source strength is practically constant and homogeneous at the surface of the continents.

\footnotetext{
* Contribution no. CFR 1033.
}

\section{Vertical distribution of radon-222}

The volume mixing ratio of radon in the lower atmosphere being of the order of $10^{-20}$, it is not possible to measure it directly or by remote sensing. All the measurements are made on air samples after appropriate separations. $\mathrm{Rn}-222$ concentrations have been intensively measured at ground level, throughout the world over continents and oceans; see, for instance, the reviews of Turekian et al. (1977) and Lambert et al. (1982).

The injection of Rn-222 from the soil surface has been measured in several different ways (Turekian et al., 1977). Most of the published values are between 0.5 and 2.5 atoms $\mathrm{cm}^{-2} \mathrm{~s}^{-1}$ (or 0.3 to $1.4 \mathrm{pCi} \mathrm{m}^{-2} \mathrm{~s}^{-1}$ ), with an average value of the order of 0.9 atoms $\mathrm{cm}^{-2} \mathrm{~s}^{-1}$ or $0.5 \mathrm{pCi} \mathrm{m}^{-2}$ $\mathrm{s}^{-1}$ (Polian et al., 1989). Moreover, Broecker et al. (1967), Hoang and Servant (1972) and Wilkening and Clements (1975) showed that the outgassing of $\mathrm{Rn}-222$ from the sea surface is about 100 times less than from continents.

In a first step, radon diffuses within the planetary boundary layer with an eddy diffusion coefficient depending on the atmospheric vertical stability, driven by the vertical gradient of temperature and the wind velocity. Near the ground, the concentration over continents is typically of the order of $100 \mathrm{pCi} \mathrm{kg}^{-1}$ during the day, reach- 
ing up to a few thousands $\mathrm{pCi} \mathrm{kg}^{-1}$ by temperature inversion. This concentration decreases with altitude up to the boundary layer upper limit. Above open oceans, the concentration generally is between 1 and $5 \mathrm{pCi} \mathrm{kg}^{-1}$ and still less over Antarctica. Rn-222 is therefore an excellent tracer of the transport of continental trace species with a comparable life-time, that is of the order of 1 week (Lambert et al., 1975; Wilkniss and Larson, 1984; Polian et al. 1986). Above the planetary boundary layer, the radon concentration decreases rapidly down to very low values (Nguyen et al., 1967; Moore et al., 1973; Lambert et al., 1982; Liu et al., 1984). It is likely that most of the vertical motions responsible for this distribution occur in convective clouds, as discussed later.

At least 3 different techniques have been used to measure $\mathrm{Rn}-222$ versus altitude. The first one consists of scooping the whole air and then, back in the laboratory, trapping gaseous radon in a cold trap with or without a molecular sieve or charcoal (Machta and Lucas, 1962). A second technique consists of directly trapping the radon in a cold trap. In both cases, the Rn-222 activity is measured in the laboratory by classical nuclear methods. The principle is rather simple, but one critical step is certainly transferring the sample from the cold trap to the measurement device without contamination by the ambient air which can contain several thousand times more $\mathrm{Rn}-222$ than the high-altitude sample. This question is of particular interest whenever an unusually high concentration is measured (see below). Many experimental results were obtained by this method (Wilkening, 1970; Moore et al., 1973). Most of the published results are summarized, and analyzed in terms of tropospheric vertical transport by Liu et al. (1984).

To avoid the above-mentioned contamination risks, Lambert et al. (1982) utilized a completely different method which consisted of filtering the air and counting, during and immediately after the sampling, the short-lived Rn-222 decay products which are fixed on aerosol particles. The balloon-borne apparatus comprised a high flow rate pump (40 kg of air per hour), one filter and a $28 \mathrm{~cm}^{2} \alpha$ scintillation counter, with an anticosmic device, just facing the filtration area. The background ranged between $0.1 \mathrm{cpm}$ at ground level and $3 \mathrm{cpm}$ at $100 \mathrm{mb}$. The counting efficiency, determined by comparison between $\alpha$ and $\beta$ activities of radon daughters, was $17 \%$. Four flights have been made from Aire-sur-l'Adour (France), according to this method (Table 1). In order to considerably increase the number of measurements on both sides of the tropopause, a similar method was used on board the NASA C-141 aircraft, over the Eastern Pacific off California and between Hawaii and the USA (Kritz et al., 1990).

Comparing the results obtained by different authors using different devices in various countries is a matter of faith. More particularly, the sampling and counting efficiencies are not really known with the desirable accuracy. However, on the whole, the results are in agreement and the profiles observed can be considered as valid: this is the basic assumption of this paper. Focusing attention on data obtained above $7 \mathrm{~km}$, two main features are observable.

First of all, although $\mathrm{Rn}-222$ concentrations normally measured near the ground are usually close to $100 \mathrm{pCi} \mathrm{kg}^{-1}$, they are extremely variable in the high troposphere: for example, from $<1$ to 32.7 in the C-141 measurements shown in Kritz

Table 1. Radon-222 concentration versus altitude obtained during 4 balloon-borne experiment flights

\begin{tabular}{|c|c|}
\hline $\begin{array}{l}\text { Flight } I \\
23 \text { October } 1977 \\
H=9.1 \mathrm{~km}\end{array}$ & $\begin{array}{l}\text { Flight } 2 \\
2 \text { November } 1978 \\
H=14 \mathrm{~km}\end{array}$ \\
\hline $\begin{array}{rl}8.7 \mathrm{~km} & 25 \pm 5 \mathrm{pCi} \mathrm{kg}^{-1} \\
11.6 \mathrm{~km} & <2.6 \mathrm{pCi} \mathrm{kg}^{-1} \\
16 \mathrm{~km} & <0.5 \mathrm{pCi} \mathrm{kg}^{-1}\end{array}$ & $\begin{array}{rr}7.2 \mathrm{~km} & 1.8 \pm 1.0 \mathrm{pCi} \mathrm{kg}^{-1} \\
8.2 \mathrm{~km} & 1.0 \pm 0.8 \mathrm{pCi} \mathrm{kg}^{-1} \\
9.2 \mathrm{~km} & 1.3 \pm 0.7 \mathrm{pCi} \mathrm{kg}^{-1} \\
10.5 \mathrm{~km} & 1.1 \pm 0.7 \mathrm{pCi} \mathrm{kg}^{-1} \\
11.4 \mathrm{~km} & 1.1 \pm 0.7 \mathrm{pCi} \mathrm{kg}^{-1} \\
11.9 \mathrm{~km} & 2.5 \pm 0.9 \mathrm{pCi} \mathrm{kg}^{-1}\end{array}$ \\
\hline $\begin{array}{l}\text { Flight } 3 \\
8 \text { March } 1979 \\
H=9.6 \mathrm{~km}\end{array}$ & $\begin{array}{l}\text { Flight } 4 \\
27 \text { April } 1980 \\
H=10.3 \mathrm{~km}\end{array}$ \\
\hline $\begin{array}{rl}7.3 \mathrm{~km} & 1.2 \pm 0.6 \mathrm{pCi} \mathrm{kg}^{-1} \\
8.3 \mathrm{~km} & 1.2 \pm 0.5 \mathrm{pCi} \mathrm{kg}^{-1} \\
9.4 \mathrm{~km} & 2.5 \pm 0.6 \mathrm{pCi} \mathrm{kg}^{-1} \\
9.9 \mathrm{~km} & 0.9 \pm 0.3 \mathrm{pCi} \mathrm{kg}^{-1} \\
12.4 \mathrm{~km} & <0.2 \mathrm{pCi} \mathrm{kg}^{-1}\end{array}$ & $\begin{array}{rl}5.8 \mathrm{~km} & 1.2 \pm 0.8 \mathrm{pCi} \mathrm{kg}^{-1} \\
7.0 \mathrm{~km} & 1.0 \pm 0.4 \mathrm{pCi} \mathrm{kg}^{-1} \\
8.2 \mathrm{~km} & 0.6 \pm 0.3 \mathrm{pCi} \mathrm{kg}^{-1} \\
9.5 \mathrm{~km} & 1.2 \pm 0.3 \mathrm{pCi} \mathrm{kg}^{-1} \\
10.3 \mathrm{~km} & 7.0 \pm 2.5 \mathrm{pCi} \mathrm{kg}^{-1} \\
11.8 \mathrm{~km} & <0.2 \mathrm{pCi} \mathrm{kg}^{-1} \\
13.2 \mathrm{~km} & <0.6 \mathrm{pCi} \mathrm{kg}^{-1}\end{array}$ \\
\hline
\end{tabular}

$H=$ tropopause altitude $(\mathrm{km})$ (Lambert et al., 1982). 
et al. (1990). Following the analyzes presented by Gidel (1983), Dikerson et al. (1987), and Kritz et al. (1990), the variations observed can be attributed both to eddy diffusion coefficient changes, especially with the altitude and season, and to advective transports connected to cumulus clouds. Several groups are now modeling radon transport (Brost and Chatfield, 1989; Zimmermann et al., 1990; Heiman et al., 1990; Jacob, 1990). It is worthwhile noting in some profiles that the Rn-222 concentration can be higher immediately beneath the tropopause than in the middle troposphere, which can be attributed to a previous ascent of that $\mathrm{Rn}-222$ in another location, followed by a horizontal advection of aloft air. Regarding the smallest values, they could be interpreted as typical of injections of stratospheric air into the troposhere. Liu et al. (1984) drew from the profiles they analyzed mean vertical profiles characteristic of the season. However, even though the general trend is an exponential decay with altitude, the deviations are important and not inconsistent with the high variability mentioned above. Moreover, it can be guessed that most of the profiles were obtained when the flight conditions were acceptable, and therefore are not representative of the average atmospheric transport. These conditions were less critical for the measurements made on board the C-141, which is a large aircraft which flew above the weather. This remark can account for the particularly great variability observed, especially by Kritz et al. (1990) and shown in Fig. 1.

The second feature is that the concentration vertical gradients are extremely sharp across the tropopause, as much as a factor 20 per $\mathrm{km}$. This is not surprising, taking into account the weakness generally expected for the troposphere-tostratosphere exchanges. In effect, similar observations were made by Cronn and Robinson (1979) for ethane, and by Rudolph et al. (1981) and Ehhalt et al. (1985) for propane and ethane, which have life-times of the order of 1 week and 1 month, respectively.

However, in the case of $\mathrm{Rn}-222$, some rare stratospheric values are much higher than usual, reaching up $15 \mathrm{pCi} \mathrm{kg}^{-1}$, i.e., quasi-tropospheric figures: see Fig. 2 comparing results from Moore et al. (1973) and Lambert et al. (1982).

In conclusion, although the $\mathrm{Rn}-222$ profiles "are by far the most extensive data compiled for

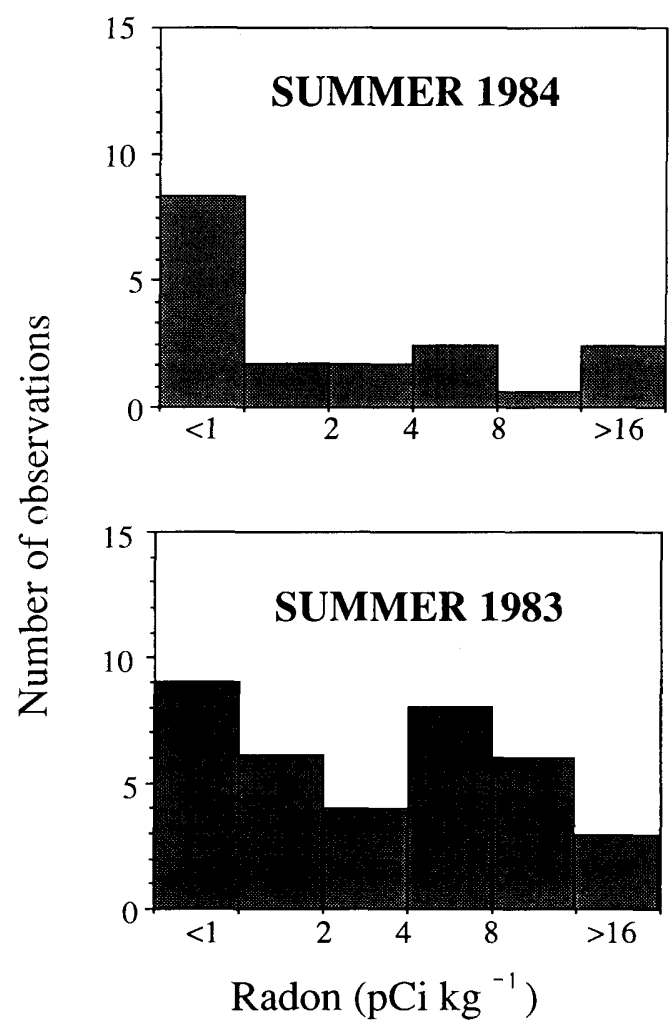

Fig. 1. Radon activity distributions in the upper troposphere (following Kritz et al., 1990).

a tropospheric tracer with simple chemistry" as pointed out by Liu et al. (1984), and despite calculations of mean seasonal vertical profiles by these authors, because of radon's short life-time and the stochastic nature of the vertical transport process, one cannot specify a single radon concentration value as characteristic of the upper troposphere. What is certain however, is that, in view of the vanishingly small concentrations of radon observed in the stratosphere, significant exchanges of radon across the tropopause must occur only in an upward direction.

\section{Radon-222 and lead-210 balance}

A very special feature of $\mathrm{Rn}-222$ is that about $30 \mathrm{~min}$ after its disintegration, it gives rise to a 20 -year half-life radio nuclide, $\mathrm{Pb}-210$, which is 


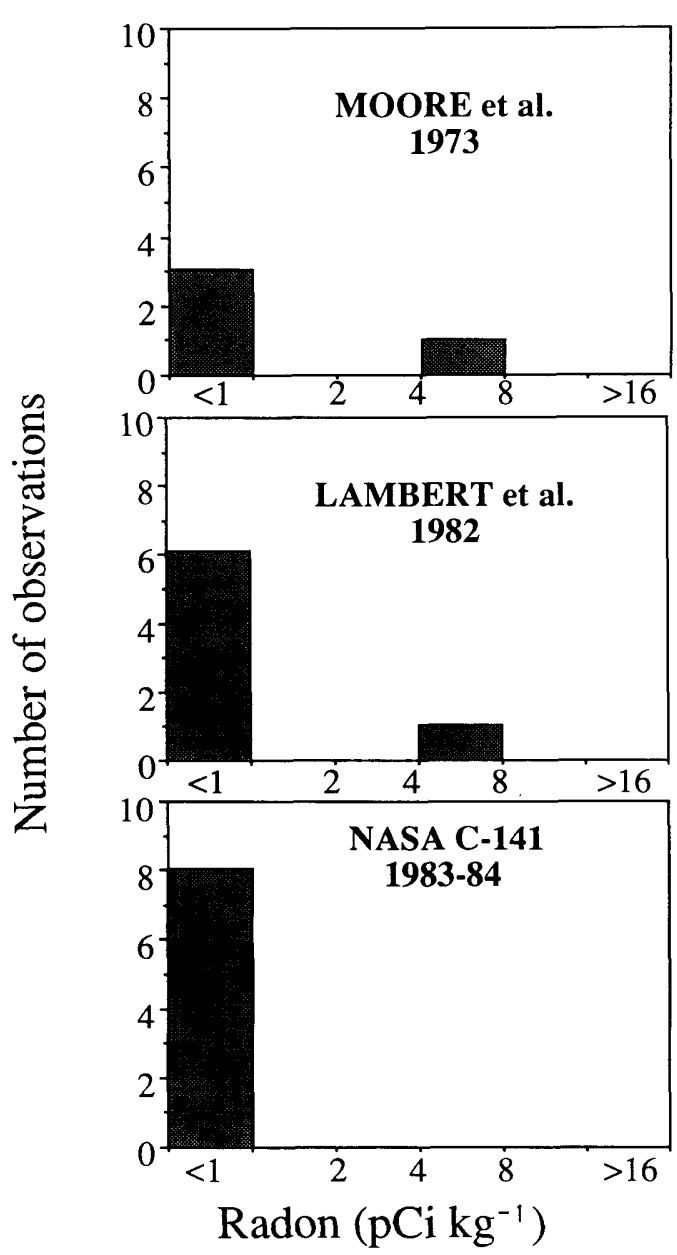

Fig. 2. Radon activity distributions in the lower stratosphere.

fixed on the aerosol particles. From the review by Lambert et al. (1982), the Pb-210 concentration at ground level varies from $20 \times 10^{-3}$ over continents to $0.5 \times 10^{-3} \mathrm{pCi} \mathrm{kg}^{-1}$ over open ocean. The activity ratios $\mathrm{Pb}-210 / \mathrm{Rn}-222$ are accounted for by an aerosol residence time close to 7 days, in agreement with many authors' measurements through different methods. As a consequence, $\mathrm{Pb}-210$ aerosols have also been used as continental tracers, especially by Graustein and Turekian (1983), and Lambert et al. (1990).

Measuring the vertical distribution of $\mathrm{Pb}-210$ is significantly easier than that of $R n-222$ for several reasons. First, $\mathrm{Pb}-210$ is present as aerosol, and large volumes of air can be filtered either by balloon-borne devices, or from aircraft equipped with isokinetic sampler. Then the halflife of $\mathrm{Pb}-210$ is long and there is practically no decay between its sampling and its subsequent measurement in the laboratory. Moreover, the counting efficiency can be accurately measured. However careful precautions must be taken in order to avoid a contamination of the filters near the soil by dusts or by low-altitude aerosols. After the exploratory measurements of Burton and Stewart (1960) made during 1954-1956, Peirson et al. (1966) have measured the $\mathrm{Pb}-210$ concentration at 4 levels: the ground, $1.3 \mathrm{~km}, 7.6 \mathrm{~km}$ and $14.3 \mathrm{~km}$. Rama and Honda (1961) have measured $3 \times 10^{-3} \mathrm{pCi} / \mathrm{SCM}$ (or $2.3 \times 10^{-3}$ pCi kg-1), $1 \mathrm{~km}$ below a $16-\mathrm{km}$ high tropopause. Moore et al. (1973) have obtained 12 profiles over USA between the mid-troposphere and the lowstratosphere with a mean concentration of $1.5 \times 10^{-3} \mathrm{pCi} / \mathrm{SCM}$ (or $1.1 \times 10^{-3} \mathrm{pCi} \mathrm{kg}^{-1}$ ) immediately beneath the tropopause, at about $11 \mathrm{~km}$ height. These values do not show significant seasonal variations and are confirmed by vertical profiles over the USSR from 1966 to 1968 (Nazarov et al., 1970) and by one balloon horizontal flight over France in 1976 (Lambert et al., 1979). On the basis of these observations, a good mean concentration immediately beneath the tropopause can be taken to be of the order of $2 \times 10^{-3} \mathrm{pCi} \mathrm{kg}^{-1}$, with an uncertainty of about $50 \%$.

A very large number of $\mathrm{Pb}-210$ measurements have been made in the stratosphere by Krey (1967, 1969 and 1975) and were summarized by Lambert et al. (1982): see Fig. 3. They are in agreement with the results of Peirson et al. (1966), Moore et al. (1973) and Lambert et al. (1979). The best mean value of the concentration of this nuclide between the tropopause and $15 \mathrm{~km}$ height is $9.2 \times 10^{-3} \mathrm{pCi} / \mathrm{SCM}$ or $7 \times 10^{-3}$ pCi kg-1.

Even though the $\mathrm{Pb}-210$ concentrations on both sides of the tropopause are not known with an accuracy better than $50 \%$, it is clear that they are about 4 times greater in the lower stratosphere than in the upper troposphere, contrary to all trace species originating from the soil surface, and consequently the $\mathrm{Pb}-210$ net exchanges across the tropopause must be going down. Now, the residence time of aerosols in the lower strato- 


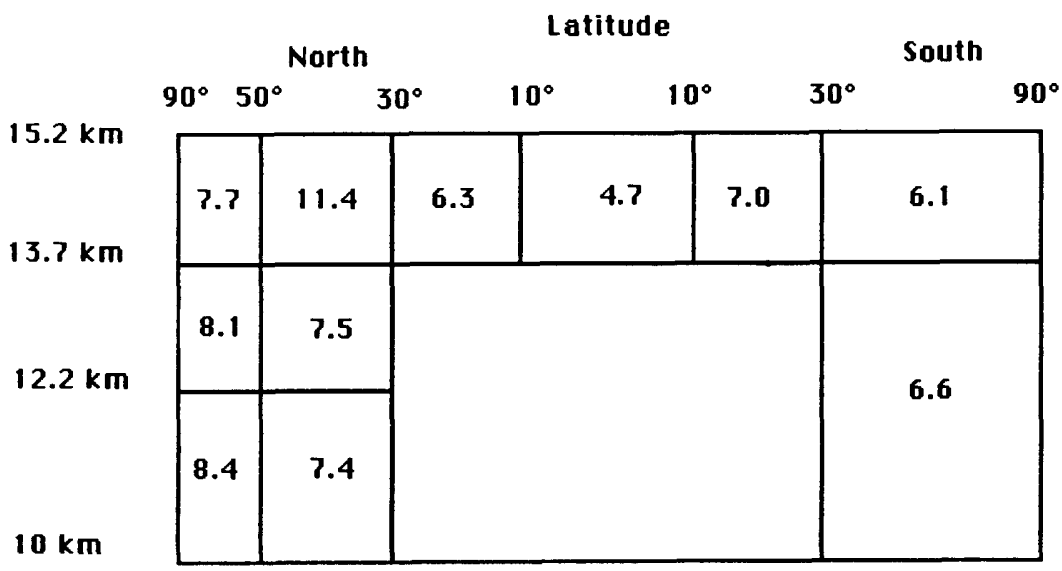

Fig. 3. $\mathrm{Pb}-210$ budget in the stratosphere (in $10^{-3} \mathrm{pCi} \mathrm{kg}^{-1}$ ) according to Lambert et al. (1982) from measurements by Krey $(1967,1969,1975)$.

sphere being several months, which is much shorter than the $\mathrm{Pb}-210$ half-life, we must have a balance, on this time basis, between the input and the output of stratospheric $\mathrm{Pb}-210$ atoms. This balance can only result from the up transfer of tropospheric $\mathrm{Rn}-222$ atoms, according to an early idea of Bandhary et al. (1966).

Let $F$ be the mean flux of air (in $\mathrm{kg} \mathrm{s}^{-1}$ ) exchanged between troposphere and stratosphere, which is obviously the same in both directions, and $C_{\mathrm{T} \uparrow}$ and $C_{\mathrm{s} \downarrow}$ the mean concentrations of $\mathrm{Pb}-210$ (in atoms $\mathrm{kg}^{-1}$ ) respectively in the high troposphere going up and in the low stratosphere going down.

The $R n-222$ flux to the stratosphere $\phi_{\mathrm{Rn}}$ (in atoms per second) necesssary to balance the $\mathrm{Pb}-210$ flux is given by:

$\phi_{\mathrm{Rn} \dagger}=F\left(C_{\mathrm{S} \downarrow}-C_{\mathrm{T} \uparrow}\right)_{\mathrm{Pb}}$.

Assuming that the stratospheric radon concentration is negligible, an acceptable value of the $\mathrm{Rn}-222$ mean concentration in the high troposphere $C_{\mathrm{Rn}}$, should therefore be:

$C_{\mathrm{Rn} \uparrow}=\frac{\phi_{\mathrm{Rn} \uparrow}}{F}=\left(C_{\mathrm{S} \downarrow}-C_{\mathrm{T} \uparrow}\right)_{\mathrm{Pb}}$,

or in radioactivity units, for the activities $a_{\mathrm{Rn}}, a_{\mathrm{S}}$ and $a_{\mathrm{T}}$ :

$$
\begin{aligned}
& a_{\mathrm{Rn}}=\lambda_{\mathrm{Rn}} \cdot C_{\mathrm{Rn}}=\frac{\lambda_{\mathrm{Rn}} \cdot\left(a_{\mathrm{S}}-a_{\mathrm{T}}\right)_{\mathrm{Pb}}}{\lambda_{\mathrm{Pb}}}, \\
& a_{\mathrm{Rn}}=\frac{0.18 \cdot(7-2) \cdot 10^{-3}}{9.5 \cdot 10^{-5} \quad \text { (for } \mathrm{Pb}-2}
\end{aligned}
$$

(for $\mathrm{Pb}-210$ : in $\mathrm{pCi} \mathrm{kg}^{-1}$ )] the radioactive constants of $\mathrm{Rn}-222$ and $\mathrm{Pb}-210$, being, respectively $0.18 \mathrm{~d}^{-1}$ and $9.5 \times 10^{-5} \mathrm{~d}^{-1}$. Finally:

$a_{\mathrm{Rn}}=10 \mathrm{pCi} \mathrm{kg}-1$.

This value is by no means an average value of the $\mathrm{Rn}-222$ concentration in the upper troposphere, but it is the mean concentration of that air which is penetrating into the stratosphere.

A comparison of this figure and the $\mathrm{Rn}-222$ concentrations reviewed in Section 2 shows that such a value is not usual in the mid-latitude upper troposphere (see Fig. 1). We can therefore ascertain that the troposphere-to-stratosphere transfers of $\mathrm{Rn}-222$ occur only in particular meteorological conditions, for which the Rn-222 is unusually enriched in the upper troposphere, that is following a rapid vertical advective transfer of this nuclide from the lower layers of the atmosphere. Moreover, it is also remarkable that such $\mathrm{Rn}-222$ concentrations were rarely observed within the stratosphere. Consequently, it seems that the troposphere-to-stratosphere exchanges should be very discontinuous, so that the chances of sampling Rn-222 immediately after its entry into the stratosphere are very weak.

\section{Conclusion}

Although the source of the atmospheric Rn-222 can be considered to be continuous and almost homogeneously spread out throughout the con- 
tinents, the concentrations of this nuclide measured in the upper troposphere vary by more than one order of magnitude. This observation is well accounted for by the variations with space and time of the tropospheric vertical transport. Even though the average concentration decreases with altitude and is well fitted by an exponential law (with different coefficients from season to season), it is impossible to directly evaluate a mean Rn-222 concentration which could characterize the high troposphere. It is therefore also impossible to parametrize a simple model assuming continuous exchanges of this nuclide across the tropopause.

However, the existence of a Rn-222 long-lived decay product, $\mathrm{Pb}-210$, enables one to determine some constraints for the troposphere-to-stratosphere exchanges. They are necessarily discontinuous in space and time, and seem to occur following an advection of air from the lower to the upper troposphere, with an equivalent mean $\mathrm{Rn}-222$ concentration of the order of $10 \mathrm{pCi} \mathrm{kg}^{-1}$. These discontinuous transfers are generally not visible in the stratosphere, but could account for rare unusual high $\mathrm{Rn}-222$ concentrations, which were actually observed, always during the months of April or May.

One consequence of this analysis is that modeling the troposphere-to-stratosphere transfers of short-lived trace species necessitates a good understanding of the transfer processes involved and an evaluation of their occurrence frequency.
In the very special case of $R n-222$, the integral calculation of these transfers has been obtained through the Pb-210 budget. Lambert et al. (1982) estimated a transfer of 77 to $164 \times 10^{18}$ atoms per minute of $\mathrm{Rn}-222$ to balance the losses of the $\mathrm{Pb}-210$ stratospheric reservoir. This corresponds to 2 to $5 \times 10^{7} \mathrm{Ci}$ per year, which at the concentration of $10 \mathrm{pCi} \mathrm{kg}^{-1}$ derived earlier, and a lower stratospheric air mass (between the tropopause and $15 \mathrm{~km}$ ) of $5 \times 10^{18} \mathrm{~kg}$, implies a residence time of the order of 4 months for the $\mathrm{Pb}-210$ aerosols in the lower stratosphere. This small value is in agreement with the results of Krey and Krajewski (1970) and Leifer et al. (1984), who calculated from different radionuclide inventories, stratopheric half-residence times of 9 and 6.5 months, respectively.

\section{Acknowledgements}

Partial support for Dr. Kritz was provided by the NASA Upper Atmospheric Research Program under Grant NCC2-502, the National Science Foundation under Grant INT-8313493 and by the CNRS (ATP "Etats-Unis" et "Atmosphere Moyenne". Balloon-borne measurements of $\mathrm{Rn}-222$ and $\mathrm{Pb}-210$ were made with the help of the CNES. Aircraft flight hours for equipment testing were kindly provided through the courtesy of Jean-Claude Revil (UTA) and Edouard Odier (Air France).

\section{REFERENCES}

Bhandary, N., Lal, D. and Rama. 1966. Stratospheric circulation studies based on natural and artificial radioactive tracer elements. Tellus $18,391-406$.

Brewer, A. W. 1949. Evidence for a world circulation provided by the measurements of helium and water vapor distribution in the stratosphere. Quart. J. Roy. Meteorol. Soc., 75, 351-363.

Broecker, W. S., Li, Y. H. and Cromwell, J. 1967. Radium-226 and Radon-222 concentration in Atlantic and Pacific oceans. Science 158, 1307-1310.

Brost, R. A. and Chatfield, R. B. 1989. Transport of radon in a three-dimensional subhemispheric model. J. Geophys. Res. 94, 5095-5119.

Burton, R. D. and Stewart, N. C. 1960 . Use of longlived natural radioactivity as an atmospheric tracer. Nature 186, 584-589.
Cronn, D. and Robinson, E. 1979. Tropospheric and lower stratospheric vertical profiles of ethane and acetylene. Geophys. Res. Lett. 6, 641-644.

Dickerson, R. R., Huffman, G. J., Luke, W. T., Nunnermacker, L. J., Pickering, K. E., Leslie, A. C. D., Lindsey, G. C., Slinn, W. G. N., Kelly, T. J., Daum, P. H., Delany, A. C., Greenberg, J. P., Zimmerman, P. R., Boatman, J. F., Ray, J. D., Stedman, D. H. 1987. Thunderstorms: an important mechanism in the transport of air pollutants. Science 235, 460-465.

Ehhalt, D. M., Rudolph, J., Meixner, F. and Schmidt, U. 1985. Measurements of selected $C_{2}-C_{5}$ hydrocarbons in the background troposphere: vertical and latitudinal variations. J. Atmos. Chem. 3, 29-52.

Feichter, J. and Crutzen, P. J. 1990. Parameterization 
of vertical tracer transport due to deep cumulus convection in a global transport model and its evaluation with 222 Radon measurements. Tellus $42 B, 100-117$.

Graustein, W. C. and Turekian, K. K. 1983. Pb-210 as a tracer of the deposition of sub-micrometer aerosols, In Precipitation Scavenging, Dry Deposition and Resuspension. Proc. 4th Intern. Conf., Santa Monica, California 1982. Edited by M. R. Pruppacher, R. G. Semonin and W. G. N. Slinn, 1315-1324. Elsevier, New York.

Gidel, L. T. 1983. Cumulus cloud transport of transient tracers. J. Geophys. Res. 88, C11, 6587-6599.

Heiman, M., Monfray, P. and Polian, G. 1990. Modeling the long-range transport of $222 \mathrm{Rn}$ to Subantarctic and Antarctic areas. Tellus 42B, 83-99.

Hoang Chi-Trach and Servant, J. 1972. Le flux de radon de la mer. (translated as: radon flux from the sea). C. R. Acad. Sci. Paris 274, 3157-3160.

Jacob, D. J. and Prather, M. J. 1990. Radon-222 as a test of convective transport in a general circulation model. Tellus 42B, 118-134.

Krey, P. W. 1967. "Project Airstream", USAEC Report No. 183

Krey, P. W. 1969. "Project Airstream", USAEC Report No. 207.

Krey, P. W. 1975. "Project Airstream", USAEC Report No. 297.

Krey, P. W. and Krajewski, B. 1970. Comparison of atmospheric transport model calculations with observations of radioactive debris. J. Geophys. Res. 75 , 2901-2908.

Kritz, M. A., Le Roulley, J. C. and Danielsen, E. F. 1990. The China Clipper: fast advective transport of radon-rich air from the Asian boundary layer to the upper troposphere near California. Tellus 42B, 46-61.

Lambert, G., Ardouin, B., Polian, G., Sanak, J. 1975. Natural radioactivity balance in the atmosphere of the Southern Hemisphere. The Natural Radiation Environment 2, conf-702805 P2, United States Energy Research and Development Administration. Office of Public Affairs/Technical Information Center.

Lambert, G., Buisson, A., Sanak, J. and Ardouin, B. 1979. Modification of the atmospheric polonium-210 to lead-210 ratio by volcanic emissions. J. Geophys. Res. 84, 6980-6985.

Lambert, G., Polian, P., Sanak, J., Ardouin, B., Buisson, A., Jégou, A. and Le Roulley, J.-C. 1982. Cycle du radon et de ses descendants: applications à l'étude des échanges troposphère-stratosphère (translated as: Radon Cycle and its daughters: applications to the troposphere-stratosphere exchange study). Ann. Géophys. 32, 497-531.

Lambert, G., Ardouin B. and Sanak, J. 1990. Atmospheric transport of trace elements toward Antarctica. Tellus 42B, 76-82.

Leifer, R., Juzdan, Z. R. and Larsen, R. 1984. The high altitude sampling program: radioactivity in the stratosphere. EML-434. US Department of Energy.

Liu, S. C., McAfee, J. R., Cicerone, R. J. 1984. Radon-222 and tropospheric vertical transport. J. Geophys. Res. 89, 7291-7297.

Machta, L. and Lucas, H. F. 1962. Radon in the upper atmosphere. Science 135, 296-299.

Moore, H. E., Poet, S. E. and Martell, E. A. 1973. ${ }^{222} \mathrm{Rn},{ }^{210} \mathrm{~Pb},{ }^{210} \mathrm{Bi}$, and ${ }^{210} \mathrm{Po}$ profiles and aerosols residence times versus altitude. J. Geophys. Res. 78, 7065-7075.

Nazarov, L. E., Kuzenkov, A. F., Malakhov, S. G. L. A., Volokitina, L. A., Gaziyer, Y. I. and Vasil'Yev, A. S. 1970. Radioactive aerosol distribution in the middle and upper troposphere over the USSR in 1963-1968. J. Geophys. Res. 75, 3575-3588.

Newell, R. J. and Gould-Stewart, S. 1981. A stratospheric fountain? J. Atmos. Sci. 38, 2789-2796.

Nguyen, B. C., Lambert G., Polian, G., Jacquin, J. P. 1967. Comparaison des distributions verticales du radon 222 de 0 à $4400 \mathrm{~m}$ au-dessus de l'océan Atlantique, du continent Antarctique et de la région parisienne (translated as: Radon-222 vertical profiles comparison from 0 to $4400 \mathrm{~m}$ over Atlantic ocean, Antarctic continent and Paris area). C. R. Acad. 265B, 1065-1068.

Peirson, D. H., Cambray, R. S. and Spicer, G. S. 1966. Lead-210 and polonium-210 in the atmosphere. Tellus $18,428-433$.

Polian, G., Lambert, G., Ardouin, B. and Jegou, A. 1986. Long-range transport of continental radon in Subantarctic areas. Tellus 38B, 178-189.

Polian, G., Monfray, P., Ardouin, B. and Lambert, G. 1989. Modélisation du transport à longue distance des masses d'air marquées par le Radon-222 (translated as: Long range transport model for radon traced air masses). Actes du Colloque sur la Recherche Française dans les Terres Australes, 417-428.

Rama and Honda, M. 1961. Natural radioactivity in the atmosphere. J. Geophys. Res. 66, 3227-3231.

Rudolph, J., Ehhalt, D. H. and Tönnissen, A. 1981. Vertical profiles of ethane and propane in the stratosphere. J. Geophys. Res. 86, C8, 7267-7272.

Turekian, K. K., Nozaki, Y. and Benninger, L. K. 1977. Geochemistry of atmospheric radon and radon products. Ann. Rev. Earth Planet Sci. 5, 227-255.

Wilkening, M. H. and Clements, W. E. 1975. Radon-222 from the ocean surface. J. Geophys. Res. $80,3828-3830$.

Wilkening, M. H. 1970. Radon 222 concentrations in the convective patterns of a mountain environment. J. Geophys. Res. 75, 1733-1740.

Wilkniss, P. E. and Larson, R. E. 1984. Atmospheric radon measurements in the Arctic; fronts, seasonal observations, and transport of continental air to Polar regions. J. Atmos. Sci. 41, 2347-2358. 